\title{
Use of Media in Indonesian Language Learning for High School Students
}

\section{Suci Lestari}

19016054

\section{Sucilestari27052001@gmail.com}

One of the success factors in learning is the teacher's ability to plan and implement learning. Effective learning activities cannot appear by themselves, but the teacher must create learning that allows students to achieve the learning objectives that have been set. Therefore, an optimal process of delivering information is needed in learning. One of the efforts to create these conditions is the optimal use of learning media.

Media is anything that can transmit messages, stimulate students' thoughts, feelings and desires so as to encourage the learning process to occur in them.bEducational media is a set of auxiliary or complementary tools used by teachers or educators in order to communicate with students or students (Suhatman Jaya, Syahrul R, 2013). In learning Indonesian the media can optimize the learning process. The use of media can also make learning fun. As research by (Syofiani et al., 2019) which states that crossword puzzles are seen as being able to improve students' language skills and students feel happy and excited to take part in learning.

In learning Indonesian, the use of media also plays a very important role in improving language skills, namely listening, speaking, reading, and writing. Therefore, learning language skills in schools does not only emphasize the theoretical aspect, but how to make students able to use language as it functions. Several studies follow the importance of using media in improving language skills. Research in 2013 by (Handayani et al., 2013) stated that the use of song media in learning poetry writing skills for class IX students of SMP N 5 Lubuk Basung plays an important role in realizing students' skills in using imagery and figure of speech in poetry. Subsequent research in 2016 by (Fitri et al., 2016) the skills of writing argumentative essays for class X SMA Negeri 5 Padang before using the TTW type cooperative learning model with the aid of image media were lower than the skills for writing argumentative essays for class X SMA Negeri 5 Padang after using the TTW type cooperative learning model with the aid of image media. Subsequent research in 2019 by (Syofiani et al., 2019) and (Putri \& R., 2019) which stated that there was a significant influence in the use of the model cooperative learning type think talk write assisted by audiovisual media to the skills or writing persuasive text for eight grade students of SMP Negeri 8 Padang.

Given the need to use media in Indonesian English learning, the author conducted a survey on the use of learning media in Indonesian language lessons. This survey is distributed throughgoogle forms with respondents 30 students of SMA Negeri 2 Kota Sawahlunto consisting of students of class X and XII. This survey contains 10 statements regarding the use of instructional media in Indonesian language lessons. 
The first statement is that the use of media in learning Indonesian is very important. The result is $46.7 \%$ strongly agree and $53.3 \%$ agree. From the survey results, the authors conclude that the use of media in learning Indonesian is very important. This is in line with the opinion (Novelti et al., 2018) which states that language has a central role in the intellectual, social, and emotional development of students. Language is a supporter of success in learning. This opinion is confirmed by Mone in (Novelti et al., 2018) which states that language learning is expected to help students get to know themselves, their culture, and other people. In addition, language is used to express ideas and feelings, participate in society, discover and use their own analytical and imaginative abilities. This opinion shows how important the position of language is, so that an effective media is needed in the delivery of language learning.

The second statement is that the teacher has used learning media that is in accordance with the Indonesian language subject matter being taught. The result is $13.3 \%$ strongly agree, $83.3 \%$ agree, and 3.4\% disagree. From the survey results, the authors can conclude that teachers have used appropriate media in learning Indonesian. According to Saud (2009: 97) appropriate, efficient, and varied media can be a good learning media. Media content that is designed according to the learning design can make quality media. Quality media will foster interest for students to learn to use media.

The third statement is that learning media have been used in learning listening, reading, reading, and writing skills. The result is $10 \%$ strongly agree, $83.3 \%$ agree, and $6.7 \%$ disagree. From the results of the survey, the authors conclude that the media has been used in language skills. This is in accordance with the objectives of learning Indonesian in the 2013 curriculum in general, which aims to make students able to master six skills, namely listening, reading, viewing, speaking, writing and serving skills (Suhatman Jaya, Syahrul R, 2013). For example, in the 2013 curriculum, Indonesian language learning is text-based learning. From all these texts it can be seen that the end of learning aboutttext is that students are able to produce/write texts (Hizati et al., 2018). In learning to write according to (Novelti et al., 2018) writing skills cannot be created without going through a process, writing skills grow and develop due to an iterative process.

The fourth statement is the use of learning media to make the material easier to understand. The result is $43.3 \%$ strongly agree, and $56.7 \%$ agree. From the survey results, the authors can conclude that the use of learning media can make the material easier to understand. The problem that is often encountered in learning according to (Hartidini \& Ratna, 2018) is the lack of teacher potential to make Indonesian language learning interesting. Students are reluctant to convey their ideas either orally or in writing. Therefore, the use of learning media can foster student interest in learning new things in the learning materials delivered by the teacher so that they can be easily understood (Nurrita, 2018).

The fifth statement is that the use of learning media makes the process of learning Indonesian more enjoyable. The result is 50\% strongly agree, and 50\% agree. From the results of the survey, the authors conclude that the use of media can make learning more fun. Sudjana and Rivai in (Nurseto, 2012) media can foster students' learning motivation because teaching will attract their attention so that students can understand and enable mastery and achievement of teaching goals. For example in research by Atmazaki in (Gustianingsih et al, 2013) said that puzzles were able to create a pleasant atmosphere.

The sixth statement is that the teacher uses learning media in the form of pictures. The result is $13.3 \%$ strongly agree, $80 \%$ agree, and $6.7 \%$ disagree. From the results of the survey, the authors conclude that teachers have used image media in Indonesian lessons. Learning using pictorial media according to Tarigan in (Suhatman Jaya, Syahrul R, 2013) is recommended by experts and pictures 
that seem silent actually say a lot for those who are sensitive and full of imagination. Therefore, the selection of images must be appropriate, interesting, and stimulating for students.

The seventh statement is that the teacher uses audiovisual media in learning Indonesian. The result is $10 \%$ strongly agree, $46.7 \%$ agree, and $43.4 \%$ disagree. From the survey results, the authors conclude that audiovisual media have been used in learning Indonesian. The benefits of audiovisual media according to (Mulyani R, Syahrul R, 2018) are used to stimulate students' thinking power in finding a main idea so that they can write it down into a text. In addition, audiovisual media can complement the basic experiences of students when they read, discuss, practice, etc. so that it is very effective in influencing and manipulating ideas before students write them down.

The eighth statement is that the teacher uses game media in learning Indonesian. The result is $30 \%$ strongly agree, $50 \%$ agree, and $20 \%$ disagree. Based on the results of the survey, the authors can conclude that teachers have used game media in learning Indonesian. The benefits of using game media according to (Syofiani et al., 2019) are that by playing children will try to have desires and achieve their desires. Through play, all aspects of a child's development can be improved. By playing freely, children can express and explore to strengthen what they already know and discover new things.

The ninth statement is that teachers use technology in learning Indonesian. The result is 43.4\% strongly agree, $50 \%$ agree, and $6.7 \%$ disagree. From the survey results, it is stated that teachers have used technology in learning. This is in line with the opinion of Ivanovic M, Javorský S, Horváth R, and Goulão MF, Fombona J in (Ramadhan et al., 2019) education must reflect actual changes and consider ways that can support the demand to provide quality conditions for human existence. in the context of the process of social transformation. Education has not escaped transformation because in a globalized world when things change, there is a need to continue education, recycle and develop it to provide answers to future challenges.

The tenth statement, media literacy has been realized in Indonesian language learning. The result is $66.7 \%$ strongly agree, and $33.3 \%$ agree. Based on the survey results, the authors can conclude that the teacher has carried out media literacy in learning. This is related to the opinion of Hobs in (Ramadhan et al., 2019) which states that media literacy is one of the basic skills that must be possessed by individuals in the 21 st century and has become a central and inseparable part of life. Media literacy can be defined as the use of mass media tools as needed, accessing the content in these tools, understanding, analyzing and evaluating messages correctly and consciously.

From the results of the data above, it can be concluded that media has been used in learning Indonesian. Teachers have used media in learning listening, speaking, reading, and writing skills. The media used in learning Indonesian are picture, audiovisual, and game media. Media technology has been used in learning Indonesian and literacy has been realized media in learning. From these results students stated that the media made it easier to understand the material and made learning more fun. However, despite all that, we as teachers must be able to choose the right media for learning. Innovation in the use of technology-based media is also needed given the increasingly sophisticated era. 


\section{Reference}

Fitri, Y. R, Syahrul, Tamsin, Andria Catri. (2016). Pengaruh Model Pembelajaran Kooperatif Tipe Think Talk Write Berbantuan Media Gambar Berseri Terhadap Keterampilan Menulis Teks Cerpen Siswa Kelas VII SMP Negeri 8 Padang. Jurnal Pendidikan Bahasa dan Sastra Indonesia, 5(2), 548-555.

Handayati, W., Syahrul, R., \& Afnita, A. (2013). Keefektifan Penggunaan Media Lagu dalam Pembelajaran Menulis Puisi Siswa Kelas IX1 SMPN 5 Lubuk Basung. Jurnal Pendidikan Bahasa dan Sastra Indonesia, 1(2), 226-232.

Hartidini, S., Syahrul, R., \& Ratna, E. (2018). Pengaruh strategi pembelajaran inkuiri berbantuan media audiovisual terhadap keterampilan menulis karangan argumentasi siswa kelas XSMA Negeri 2 Lengayang kabupaten pesisir selatan. Jurnal Pendidikan Bahasa dan Sastra Indonesia, 7(1), 63-69.

Hizati, A., Ramadhan, syahrul, \& Arief, E. (2018). Pengaruh Model Problem Based Learning Berbantuan Media Gambar Berseri Terhadap Keterampilan Menulis Teks Eksplanasi Siswa Kelas Viii Smp Negeri 12 Padang. Pendidikan Bahasa Dan Sastra Indonesia, 7(1), 183-190. https://doi.org/10.31227/osf.io/mh6e3.

Mulyani, R., \& Syahrul, R. (2020). Pengaruh Model Pembelajaran Kooperatif Tipe Think Talk Write (TTW) Berbantuan Media Audiovisual terhadap Keterampilan Menulis Teks Persuasi Siswa Kelas VIII SMP Negeri 8 Padang. Jurnal Pendidikan Bahasa dan Sastra Indonesia, 8(3), 374-382.

Ningsih, A. G., \& Syahrul, R. (2013). Peningkatan Keterampilan Berbicara Melalui Metode Bermain Teka-Teki Siswa Kelas X MAS-TI Tabek Gadang Kabupaten Lima Puluh Kota. Bahasa, Sastra, dan Pembelajaran, 1(3).

Novelti, N., Ramadhan, S., Ermanto, E., \& Agustina, A. (2018). Developing an Instructional Model Assisted Audio Visual Media. 263(Iclle), 111-116. https://doi.org/10.2991/iclle-18.2018.17.

Nurrita, T. (2018). Pengembangan Media Pembelajaran Untuk Meningkatkan Hasil BelajarSiswa. MISYKAT: Jurnal Ilmu-Ilmu Al-Quran, Hadist, Syari'ah Dan Tarbiyah, 3(1), 171. https://doi.org/10.33511/misykat.v3n1.171.

Nurseto, T. (2012). Membuat Media Pembelajaran yang Menarik. Jurnal Ekonomi Dan Pendidikan, 8(1), 19-35. https://doi.org/10.21831/jep.v8i1.706.

Putri, R. D., \& Syahrul, R. (2019). Pengaruh Penggunaan Teknik Think Talk Write (TTW) Terhadap Keterampilan Menulis Teks Fabel Siswa Kelas VII SMP Negeri 31 Padang. Jurnal Pendidikan Bahasa dan Sastra Indonesia, 8(2), 66-73.

Ramadhan, S., Sukma, E., \& Indriyani, V. (2019). Teacher competence in utilizing digital media literacy in education. Journal of Physics: Conference Series, 1339(1). https://doi.org/10.1088/1742-6596/1339/1/012111. 
Saud, Udin Syaefuddin. (2009). Inovasi Pendidikan. Bandung: Alpabeta.

Suhatman Jaya, Syahrul R, E. (2013). Peningkatan Keterampilan Menulis Puisi Melalui Media Gambar Siswa Kelas X.1 Sma Negeri 2 Kota Sungai Penuh. Journal of Chemical Information and Modeling, 53(9), 1689-1699.

Syofiani, S., Zaim, M., Ramadhan, S., \& Agustina, A. (2019). Peningkatan Keterampilan Berbahasa Siswa Melalui Pemanfaatan Media Teka-Teki Silang: Menciptakan Kelas Yang Menyenangkan. Ta'dib, 21(2), 87. https://doi.org/10.31958/jt.v21 

